\title{
Language as assault: Nathalie Stephens' L'Injure
}

\author{
John Stout
}

\begin{abstract}
À la fois un long «J'accuse» contre l'anti-sémitisme et une recherche de l'identité, L'Injure de Nathalie Stephens, publié en 2004, constitue une nouvelle étape dans la poétique de cette auteure. Dans ses livres précédents - Colette m'entends-tu?, Underground ou Je Nathanaël le rapport du sujet lesbien ou transgender à la langue et à l'écriture se trouvait mis en valeur. Avec L'Injure, Stephens explore les forces liant l'identité et la langue à la violence et à la honte afin de dépasser, si possible, une impasse qui rend l'identité juive (im)possible.
\end{abstract}

A struggle with-and against-language and identity is central to the work of Nathalie Stephens. As a bilingual writer, Stephens remains at once possessed and dispossessed both by French and by English. (Born in 1970, she has to date published several books of poetry and chapbooks in each of these languages). Her attachment to French is intense. French is (literally) her mother('s) tongue and a conduit to a complex cultural and literary heritage. Yet, because she has lived almost all her life in anglophone places (Ontario and, now, Chicago), her relationship to French also marginalizes her. At the same time, because she practises experimental writing, her work in English has been similarly marginalized in anglophone cultures. Stephens' project-to explore her Sephardic Jewish heritage through writing - further complicates and enriches her poetry.

Gender and sexuality, as well as the relationships of both of these issues to language, constitute another vital concern of Stephens' creative imagination. Her texts Colette m'entends-tu? (1977), Underground (1999) and Somewhere Running (2000) - which can be read as a lesbian trilogy - reflect the energies of a young lesbian feminist writer labouring to transform language and other systems of representation, to break the (signifying) chains of heteropatriarchal logic. Referencing the writings of such lesbian precursors as Colette, Gertrude Stein and Nicole Brossard, this trilogy succeeds in dismantling conventional approaches to representation, as Stephens fragments narrative to reimagine the place of the lesbian subject in language.

In more recent books, Stephens has been engaged in a process of linguistic transgendering. In All Boy (2001) and in Je Nathanaël (2003), via the queer muse of Gide's Les Nourritures terrestres with its call to sexual and personal freedom, the first-person speaker shifts from female to male, from Nathalie to Nath(anaël). Again, Stephens pursues a questioning and reworking of language to introduce new possibilities of identity.

The assumption of a male/masculine persona continues in L'Injure (2004). L'Injure unfolds as a series of brief, harsh passages of poetic prose of often 
unbearable intensity. This text confronts the reader with fragments from a long history of violence and shaming. Anti-semitic violence, both verbal and literal, has marked the sense of self of the man who enters Stephens' text "from far away" as $L$ 'Injure opens: "Il arrive de loin [. . . Il Il avance au pas de ceux contre qui le temps cogne comme une injure. Il en est cicatrisé, tailladé" (17). "Il arrive de loin. Un Juif arrive de loin. Une Juive de plus loin encore" (18).

This unknown man (whose only words of dialogue in $L$ 'Injure are "Blue [. . .] I am Blue" repeated in several different passages) is sometimes described in the third person singular by a narrator, sometimes addressed directly using the "tu" (familiar) form of the second person singular in French. This switching back and forth of pronominal use suggests an instability or dividedness in (this) Jewish (man's) identity.

L'Injure reads like a sort of " $J$ 'accuse" confronting anti-semitism with full force. Only by acknowledging the long existence of shame and violation can a catharsis be achieved, Stephens implicitly asserts as she performs shaming.

Language and geography provide a focal point for the exploration of identity and exile in this text: "Fallait-il dire la France [...]?", "Fallait-il dire l'Algérie [. . . ]?", "Fallait-il dire le Canada?", "Fallait-il dire l'Espagne?", "Ou le Maroc [. . .]?", "Fallait-il dire Israël [ . . .]?":

Là où je suis
Fuite (19-20)

Language is associated with impossibility and absence: "À quoi reconnaître ses mots à lui? [. . .] Quelle langue ose-t-il parler? Celle de Wagner? De Céline? D'Eliot? Celle du Christ? Celle de Buber? De Weil?" (42). If, as this quote implies, all available languages are tainted by hate and violence, (how) can language be appropriated? "Mais la langue est la première impasse," the narrator writes, "l'annonce de l'égarement. La brèche où s'accomplit l'oubli" (43). These aporias of identity lead to a chilling cry of despair: "I don't want to be a Jew anymore"(43).

However, this yielding to despair is only temporary. Stephens' Jew continues his quest, follows his dream of identity recovery, come what may. Towards the end of $L$ 'Injure, she writes: "Fallait-il se méprendre sur le lien de sa naissance? [. . . ] Toujours aux lèvres la langue jamais parlée. La langue fossoyée. Tapissée dans le creux du rêve inavoué" (60). In the final line, she reasserts the need for naming, in spite of the insufficiencies and indignities that characterize all languages: "Que te reste-t-il? [. . .] Le désir, suffocant, inexécutable, de nommer" (64).

The continual series of questions which emerges on page after page of L'Injure helps the reader to understand Stephens' purpose here. In Le Livre des questions, the great French-Jewish poet Edmond Jabès wrote at one point that the Jew is a person who answers a question with another question. Stephens' privileging of the question in her text signifies at once an inability to fix identity by stating categorically who one is, where one belongs, which linguistic community 
defines one. Just as urgently, her foregrounding of the question constitutes, in itself, an assertion of pride in (non-)identity. In the interstices between French, English, Spanish, German, Yiddish and Hebrew, a sense of Jewish identity can be glimpsed, even as the poet confronts us with more questions and with an unfinished project of commemoration and searching.

\section{Works Cited}

Jabès, Edmond. Le Livre des questions. Paris: Gallimard, 1963. Stephens, Nathalie. Colette m'entends-tu? Laval: Trois, 1997.

- Underground. Laval: Trois, 1999.

- Somewhere Running. Vancouver: Arsenal Pulp Press, 2000.

- All Boy [2001]. Toronto: Bookthug, 2004.

- Je Nathanaël. Montréal: L'Hexagone, 2003.

- L'Injure. Montréal: L'Hexagone, 2004. 